\title{
Drug resistance patterns of Salmonella isolates of equine origin from India
}

\author{
Bhoj Raj Singh ${ }^{1}$, Jatinder Jyoti ${ }^{2}$, Mudit Chandra ${ }^{3}$, N Babu $^{4}$, G Sharma $^{4}$ \\ 'ICAR' Research Complex for NEH Region, Nagaland Centre, Medziphema, Jharnapani-797 106, Nagaland, India \\ ${ }^{2}$ Civil Veterinary Hospital, Faijullah Chak, Gurdaspur-143521, India. \\ ${ }^{3}$ Veterinary Microbiology, College of Veterinary Sciences, GADVAS University, Ludhiana-141 001, Punjab \\ ${ }^{4}$ Equine Breeding Stud, Babugarh, Ghaziabad, India.
}

\begin{abstract}
Introduction: Salmonellosis is a zoonosis, and one of the most serious public health and animal health problems.

Methodology: We studied 111 isolates of Salmonella belonging to 14 S. enterica subspecies enterica serovars namely $S$. Abortusequi (45), $S$. Weltevreden (1), S. Dumfries (2), S. Tshiongwe (1), S.I. 4,5,12:r,i:1,5 (12), S. Bovismorbificans (3), S. Drogana (8), S. Lagos (4), S. Kottbus (3), $S$. Richmond (1), S. Typhimurium (6), S. Newport (7), S. Paratyphi B var Java (17) and $S$. Saintpaul (5) isolated from equids in India. Results: All strains studied were resistant to one or more antimicrobials. Strains were resistant to ampicillin (18, 16\%), ampicillin+cloxacillin $(6,5 \%)$, cefotaxime $(6,5 \%)$, chloramphenicol $(2,2 \%)$, ciprofloxacin $(9,8 \%)$, gentamicin $(27,24 \%)$, kanamycin $(37,33 \%)$, nalidixic acid $(10,9 \%)$, furazolidone $(97,87 \%)$, streptomycin $(33,30 \%)$, sulphamethoxazole $(91,82 \%)$, tetracycline $(48,43 \%)$ and trimethoprim $(5,4.5 \%)$. Multiple-drug-resistance was detected in $84(75.7 \%)$ isolates and was seen in isolates of all serovars except of $S$. Kottbus, a rare serovar in India. Salmonella isolates could be classified into 51 resistotypes but 47 (42.3\%) isolates belonged to six major resistotypes. Resistotype 13 (resistant to furazolidone, sulphamethoxazole and tetracycline) was most common, followed by resistotype 19 (resistant to nalidixic acid, sulphamethoxazole and tetracycline), resistotype 28 (resistant to furazolidone, streptomycine, sulphamethoxazole and tetracycline) and resistotype 40 (resistant to furazolidone, gentamycin, kanamycin, streptomycine, sulphamethoxazole and tetracycline) including $11,8,8$ and 7 strains of different serovars, respectively.

Conclusions: This study revealed that antimicrobial drug resistance was common in Salmonella isolates from equids even towards those drugs not used in equids.
\end{abstract}

Keywords: Salmonella, MDR, equids, Antibiotic resistance

J Infect Developing Countries 2009; 3(2):141-147.

Received 14 May 2008 - Accepted 17 October 2008

Copyright $\odot 2009$ Singh et al. This is an open-access article distributed under the Creative Commons Attribution License, which permits unrestricted use, distribution, and reproduction in any medium, provided the original work is properly cited.

\section{Introduction}

Salmonellosis is a zoonosis, and one of the most serious public health and animal health problems. Almost all warm-blooded and many cold-blooded animals are its natural hosts. It may vary in severity from undetectable infections to acute disease, which may be fatal to the very young, the old, or the debilitated individual. Salmonellosis in equids is a global problem with varying severity and prevalence varying from less than $2 \%$ to about $27 \%$ depending upon the topography and climatic conditions $[1,2,3,4]$.

The earliest report of salmonellosis in equids was from cases of abortion in mares [5,6]; causative organism was identified as Salmonella abortusequi, now known as $S$. enterica subsp. enterica serovar Abortusequi ( $S$. Abortusequi). Earlier $S$. Abortusequi was found globally; however, today the infections are mostly limited to Asian and African countries.
Salmonella Typhimurium is another serovar commonly isolated from horses [7,8,9]. More recently, a number of other Salmonella serovars have also been recovered from equids [2,3,10-12]. In recent studies, Salmonella bacteria could be isolated from $2 \%$ to $15 \%$ of apparently healthy equids while Salmonella DNA could be detected by PCR from $27 \%$ to $40 \%$ equids $[2,3,4]$.

The majority of Salmonella infections in equids are iatrogenic [13]. Important risk factors, which lead to precipitation of Salmonella infection in equids, include administration of antimicrobials, colic, surgery, and transportation stress. Animals with severe neutropenia (due to either any immunodeficiency problem or to prolonged anticancer chemotherapy) are also at increased risk for bacterial and fungal infections. [14-16].

Antimicrobial resistance in disease-causing 
Table 1. Antimicrobial drug resistance in Salmonella isolates of equine origin in India.

\begin{tabular}{|c|c|c|c|c|c|c|}
\hline Salmonella Serovars & Total & $\mathbf{A}$ & Ac & $\mathrm{Ce}$ & C & Cf \\
\hline S. Abortusequi & 45 & 3 & 0 & 2 & 0 & 5 \\
\hline S. Bovismorbificans & 3 & 1 & 1 & 1 & 0 & 0 \\
\hline S. Drogana & 8 & 1 & 0 & 1 & 0 & 0 \\
\hline S. Dumfries & 2 & 0 & 0 & 0 & 0 & 0 \\
\hline S. Kottbus & 3 & 0 & 0 & 0 & 0 & 0 \\
\hline S. Lagos & 4 & 0 & 0 & 0 & 0 & 0 \\
\hline S. Newport & 7 & 0 & 0 & 0 & 0 & 0 \\
\hline S. Paratyphi B Java & 17 & 7 & 1 & 1 & 1 & 2 \\
\hline S. Richmond & 1 & 1 & 1 & 0 & 0 & 0 \\
\hline S. Saintpaul & 5 & 1 & 1 & 1 & 1 & 0 \\
\hline S.I. 4,5,12:ri:i,5 & 12 & 3 & 1 & 0 & 0 & 0 \\
\hline S. Tshiongwe & 1 & 0 & 0 & 0 & 0 & 0 \\
\hline S. Typhimurium & 6 & 0 & 0 & 0 & 0 & 1 \\
\hline S. Weltevreden & 1 & 1 & 1 & 0 & 0 & 1 \\
\hline Total Isolates & 111 & 18 & 6 & 6 & 2 & 9 \\
\hline Percent resistant & 100 & 16.2 & 5.4 & 5.4 & 1.8 & 8.1 \\
\hline \multicolumn{7}{|c|}{$\begin{array}{l}\text { bacteria results in increased illness, deaths, and } \\
\text { increased health-care costs [17-18]. Emergence of } \\
\text { multi-drug-resistance (MDR) in empirical } \\
\text { antimicrobial agents is a global problem, particularly } \\
\text { in pathogens causing nosocomial infections. The } \\
\text { increasing use of indwelling devices, as well as } \\
\text { widespread and indiscriminate use of antibacterial } \\
\text { agents in hospital settings, contributes to } \\
\text { antimicrobial resistance among pathogens causing } \\
\text { nosocomial infections [17, 19]. Although, much work } \\
\text { has been conducted on the emergence of } \\
\text { antimicrobial resistance to Salmonella in human } \\
\text { health, [20-22], little is known about antimicrobial } \\
\text { resistance in Salmonella strains prevalent in equids in } \\
\text { India. We conducted antimicrobial drug sensitivity } \\
\text { tests on } 111 \text { Salmonella isolates from equids isolated } \\
\text { from different parts of India [12] and detected MDR } \\
\text { in more than75\% of the isolates. }\end{array}$} \\
\hline
\end{tabular}

\section{Material and Methods}

Salmonella isolates
Salmonella isolates (111) belonging to 14 serovars (Abortusequi, Weltevreden, Dumfries, Tshiongwe, 4,5,12:r,i:i,5, Bovismorbificans, Drogana, Lagos, Kottbus, Richmond, Typhimurium, Newport, Paratyphi B var Java, and Saintpaul) of $S$. enterica subspecies enterica (Table 1) were obtained from stocks at the National Salmonella Centre (Vet), Indian Veterinary Research Institute, Izatnagar, repository. All were confirmed through biochemical and serological methods [23] and maintained on nutrient agar slopes until tested. All $S$. Abortusequi isolates included in the study were isolated between 1982 and 1996 at Izatnagar from aborted fetal tissues and vaginal swabs submitted for diagnosis $[10,12]$, while strains of other Salmonella serovars were isolated after 1991 either from healthy or apparently healthy equids [2,12,27] except for one $S$. Typhimurium isolate from a diarrhoeic foal [11].

\section{Antimicrobial sensitivity assay}

Antimicrobial sensitivity of Salmonella isolates was determined in triplicate by disc diffusion method 
on Mueller Hinton agar No. 4 using ampicillin $10 \mu \mathrm{g}$ (Am), ampicillin+cloxacillin $20 \mu \mathrm{g} \quad$ (Ac), chloramphenicol $30 \mu \mathrm{g}(\mathrm{C})$, cefotaxime $30 \mu \mathrm{g}(\mathrm{Ce})$, ciprofloxacin $5 \mu \mathrm{g}(\mathrm{Cf})$, furazolidone $300 \mu \mathrm{g}(\mathrm{F})$, gentamicin $10 \mu \mathrm{g}(\mathrm{G})$, kanamycin $30 \mu \mathrm{g}(\mathrm{K})$, nalidixic acid $30 \mu \mathrm{g}(\mathrm{Na})$, streptomycin $10 \mu \mathrm{g}(\mathrm{S})$, sulphamethoxazole $300 \mu \mathrm{g}(\mathrm{Sm})$, tetracycline $30 \mu \mathrm{g}$ (T) and trimethoprim $5 \mu \mathrm{g}(\mathrm{Tm})$ discs (Hi-media, Mumbai). Based on zone of inhibition, isolates were classified as sensitive or resistant according to CLSI (2006) standards. The strains resistant to three or more drugs were classed as multi-drug-resistant (MDR) strains. A reference E. coli K12 strain (E382), sensitive to all antimicrobials was used as control.

\section{Results}

All 111 isolates were resistant to one or more antimicrobials. Resistance rate varied from $2 \%$ to $87 \%$ as follows: ampicillin (18, 16\%), ampicillin+cloxacillin $(6,5 \%)$, cefotaxime $(6,5 \%)$, chloramphenicol $(2,2 \%)$, ciprofloxacin $(9,8 \%)$, gentamicin $(27,24 \%)$, kanamycin $(37,33 \%)$, nalidixic acid (10, 9\%), furazolidone (97, 87\%), streptomycin $(33,30 \%)$, sulphamethoxazole (91, $82 \%)$, tetracycline $(48,43 \%)$, and trimethoprim (5, $4.5 \%)$.

As shown in Table 2, the majority of the Salmonella isolates $(99,89.2 \%)$ were resistant to more than one antimicrobial drug as follows: to seven $(2.7 \%)$, six $(5.4 \%)$, five $(19.8 \%)$, four $(18.9 \%)$, three $(28.8 \%)$, two $(13.5 \%)$, and one $(10.8 \%)$ drug. Multiple drug resistance (MDR), defined as resistance to three or more antimicrobials, was seen in $84(75.7 \%)$ of the Salmonella isolates. MDR was recorded in strains of all $S$. enterica serovars to a variable extent, including $S$. Abortusequi (58.9\%), $S$. Weltevreden (100\%), S. Dumfries (100\%), $S$. Tshiongwe (100\%), S. I. 4,5,12:r,i:1,5 (91.7\%), S. Bovismorbificans (66.7\%), S. Drogana (100\%), $S$. Lagos (100\%), $S$. Richmond (100\%), $S$. Typhimurium (83.3\%), S. Newport (100\%), $S$. Paratyphi B var Java (84.6\%), and S. Saintpaul $(100 \%)$ (Table 2). MDR was not found in the three strains of $S$. Kottbus (Table 2).

Although 111 isolates of 14 serovars belonged to 51 resistotypes, $43 \%$ belonged to six major resistotypes (Table 3). Resistotype 13 (resistant to furazolidone, sulphamethoxazole and tetracycline) was the most common, followed by resistotype 19 (resistant to nalidixic acid, sulphamethoxazole and tetracycline), resistotype 28 (resistant to furazolidone, streptomycine, sulphamethoxazole and tetracycline), and resistotype 40 (resistant to furazolidone, gentamycin, kanamycin, streptomycine, sulphamethoxazole and tetracycline) comprising 11 , 8,8 and 7 strains of different serovars, respectively.

\section{Discussion}

In absence of regulations regarding the use of antimicrobials in domestic animals in India, there is no restriction on use of antimicrobials intended for human use and choice of drug often depends on economic availability of the medicine [25,26]. In equids, penicillins, tetracyclines, gentamicin, cotrimoxazole, cefotaxime, ampicillin and kanamycin are often the drugs of choice, but many veterinarians also use quinolones, third-generation cephalosporins, and new generation aminoglycosides [25,26]. MDR in Salmonella isolates and other bacteria is increasingly common in clinical as well as nonclinical samples of equine origin in India $[26,27]$ and it might be associated with indiscriminate drug use of antimicrobials in animals and potentially in human beings in India $[25,26]$.

Although use of sulfonamides, furazolidone and tetracycline is minimal in equids $[25,26,28]$, the majority of Salmonella isolates of equine origin were resistant to sulfamethoxazole $(82 \%)$, furazolidone $(87 \%)$ and tetracycline $(43 \%)$. This pattern of MDR might be attributed to widespread use of these antimicrobials as empirical therapy of febrile syndromes in humans and other animals, as well as to the use of these antimicrobials as growth-enhancers in animal production $[25,26,29,30]$. Resistance to sulfamethoxazole in MDR Salmonella has been prevalent for three decades among human isolates in India [30, 31] and communicability of Salmonella between human and animals [32, 33] might be responsible for the similar pattern in Salmonella isolates from equids and from other animals. Resistance to similar drugs is reported in Salmonella isolated from food, water [21,22] and in different animals [34] in India.

Horse meat is rarely consumed in India and neighbouring countries, but spread of salmonellosis from horses carrying MDR Salmonella to other livestock reared for meat or milk or other products and even to persons caring for horses is a possibility facilitating circulation of MDR strains [35]. Animals scavenging on dead horses, or dogs and other pet animals fed on horse meat, may also acquire 
Salmonella infection from contaminated horse meat/

Table 2. Multiple drug resistance (MDR) among Salmonella of equine origin in India.

\begin{tabular}{|c|c|c|c|c|c|c|c|c|c|}
\hline \multirow[t]{2}{*}{ Salmonella Serovars } & \multirow{2}{*}{$\begin{array}{l}\text { Numbers } \\
\text { Tested }\end{array}$} & \multicolumn{7}{|c|}{ Number of drugs resisted } & \multirow{2}{*}{$\begin{array}{l}\% \text { Of isolates showing } \\
\text { resistance to } \geq 3 \text { drugs(MDR) }\end{array}$} \\
\hline & & 7 & 6 & 5 & 4 & 3 & 2 & 1 & \\
\hline S. Abortusequi & 45 & 1 & 3 & 7 & 6 & 9 & 11 & 8 & 58.9 \\
\hline S. Weltevreden & 1 & 1 & 0 & 0 & 0 & 0 & 0 & 0 & 100.0 \\
\hline S. Dumfries & 2 & 0 & 0 & 1 & 1 & 0 & 0 & 0 & 100.0 \\
\hline S. Tshiongwe & 1 & 0 & 0 & 0 & 1 & 0 & 0 & 0 & 100.0 \\
\hline S.I. 4,5,12:r,i:i,5 & 12 & 1 & 0 & 2 & 6 & 2 & 1 & 0 & 91.7 \\
\hline S. Bovismorbificans & 3 & 0 & 0 & 0 & 2 & 0 & 0 & 1 & 66.7 \\
\hline S. Drogana & 8 & 0 & 0 & 1 & 1 & 6 & 0 & 0 & 100.0 \\
\hline S. Lagos & 4 & 0 & 0 & 0 & 0 & 4 & 0 & 0 & 100.0 \\
\hline S. Kottbus & 3 & 0 & 0 & 0 & 0 & 0 & 0 & 3 & 0.0 \\
\hline S. Richmond & 1 & 0 & 0 & 0 & 1 & 0 & 0 & 0 & 100.0 \\
\hline S. Typhimurium & 6 & 0 & 0 & 0 & 1 & 4 & 1 & 0 & 83.3 \\
\hline S. Newport & 7 & 0 & 1 & 5 & 0 & 1 & 0 & 0 & 100.0 \\
\hline S. Paratyphi B Java & 13 & 0 & 2 & 5 & 1 & 3 & 2 & 0 & 84.6 \\
\hline S. Saintpaul & 5 & 0 & 0 & 1 & 1 & 3 & 0 & 0 & 100.0 \\
\hline Total & 111 & 3 & 6 & 22 & 21 & 32 & 15 & 12 & 75.7 \\
\hline Percent resistant & 100 & 2.7 & 5.4 & 19.8 & 18.9 & 28.8 & 13.5 & 10.8 & 75.7 \\
\hline
\end{tabular}

flesh and may have a significant role in the spread of salmonellosis in the environment [32,33]. Prevalence of Salmonella isolates from equids resistant to drugs used in human patients and also in the strains belonging to serovars often causing salmonellosis in human but not in equids ( $S$. Paratyphi B) indicates the similar possibility of the circulation of MDR strains in the environment and among horses, one of the natural hosts for this dreaded pathogen. Moreover, the possibility of the spread of MDR Salmonella infection through horse meat exported to the consumer countries cannot be excluded, and one such outbreak of MDR $S$. Newport (the serovar also present in Indian horses) recently occurred in France [36]. Salmonella serovars similar to those in equids of India have also been reported frequently from meat and excretions of horses in other countries [32,33,35-38].

Apart from resistance to sulfamethoxazole and furazolidone, $S$. Abortusequi isolates were more often resistant to ciprofloxacin, gentamicin, kanamycin and streptomycin but rarely to tetracycline (Table 1). Ciprofloxacin, gentamicin, kanamycin, and streptomycin are commonly used and tetracyclines are rarely used drugs in equids in India [25,26]. The presence of Salmonella Abortusequi, being a hostadapted Salmonella rarely isolated from other animals and sources [12], indicated that empirical drug use affects the emergence of drug resistance in Salmonella $[30,39,40]$ even in cases when the causal agent is not directly hit by the treatment. Resistance to chloramphenicol in only $S$. Paratyphi B and $S$. Saintpaul, common serovars in human patients in
India, further indicates that Salmonella probably circulates in different animals and humans; and empirical drug use resulting in emergence of resistant strains in one host might be responsible for similar resistance in other hosts where the concerned drug is not used. Chloramphenicol is rarely used in animals, but it is the most commonly used antibiotic in humans for treatment of typhoid and paratyphoid fever [30,31].

Nalidixic acid and ciprofloxacin resistance in isolates of $S$. Abortusequi, $S$. Typhimurium, $S$. Paratyphi B and $S$. Weltevreden is also significant because it is associated with higher MICs for other fluoroquinolones rendering them clinically ineffective in spite of sensitivity shown by disc diffusion method in vitro [30,41]. Ciprofloxacin and enerofloxacin are the commonly used drugs in equids in India [25,26] which might have selected for resistance to fluoroquinolones.

Predominance of MDR among Salmonella isolates from equids is of particular importance because of the apparent risk to humans acquiring zoonotic Salmonella through contact with horses. Although there is no microbiologically proven link between antimicrobial resistance and virulence for humans in zoonotic Salmonella, increased rates of hospitalisation have been reported for patients with infections with MDR S.Typhimurium [29]. Multiple drug resistance to empirically used drugs is anticipated; however, resistance to chloramphenicol and tetracyclines, rarely used in horses, is surprising because emergence of drug-resistant Salmonella is thought to be due to selective pressure from the use 
of antimicrobials. Maintenance of drug resistance

Table 3. Resistotypes (R-types) among Salmonella isolates of equine origin in India.

\begin{tabular}{|c|c|c|c|}
\hline R-type & Resistant to antimicrobials & Nos. & Serovars of Salmonella isolates showing resistance pattern \\
\hline 1 & $\mathrm{~F}$ & 7 & S. Abortusequi (7) \\
\hline 2 & $\mathrm{Sm}$ & 4 & S. Abortusequi (1), S. Kottbus (3) \\
\hline 3 & $\mathrm{~T}$ & 1 & S. Bovismorbificans (1) \\
\hline 4 & $\mathrm{~A}, \mathrm{~F}$ & 1 & S. Abortusequi (1) \\
\hline 5 & $\mathrm{~F}, \mathrm{G}$ & 1 & S. Abortusequi (1) \\
\hline 6 & $\mathrm{~F}, \mathrm{~K}$ & 4 & S. Abortusequi (4) \\
\hline 7 & $\mathrm{~F}, \mathrm{Sm}$ & 4 & S. Abortusequi (4) \\
\hline 8 & $\mathrm{G}, \mathrm{Sm}$ & 1 & S. Abortusequi (1) \\
\hline 9 & $\mathrm{Sm}, \mathrm{T}$ & 1 & S.I. 4,5,12:ri:i,5 (1) \\
\hline 10 & $\mathrm{Na}, \mathrm{Sm}$ & 3 & $S$. Typhimurium (1), S. Paratyphi B var Java (2) \\
\hline 11 & $\mathrm{~A}, \mathrm{Ac}, \mathrm{F}$ & 1 & S. Saintpaul (1) \\
\hline 12 & $\mathrm{~F}, \mathrm{~K}, \mathrm{~S}$ & 1 & S. Abortusequi \\
\hline 13 & $\mathrm{~F}, \mathrm{Sm}, \mathrm{T}$ & 11 & S. Abortusequi (1), S. Drogana (6), S. Lagos (2), S.I. 4,5,12:r,i:i,5 (2) \\
\hline 14 & $\mathrm{~F}, \mathrm{~S}, \mathrm{~T}$ & 2 & S. Lagos (2) \\
\hline 15 & $\mathrm{~F}, \mathrm{G}, \mathrm{Sm}$ & 1 & S. Newport (1) \\
\hline 16 & $\mathrm{~F}, \mathrm{~K}, \mathrm{Sm}$ & 6 & S. Abortusequi (6) \\
\hline 17 & $\mathrm{~F}, \mathrm{Na}, \mathrm{Sm}$ & 1 & S. Typhimurium (1) \\
\hline 18 & $\mathrm{G}, \mathrm{Na}, \mathrm{Sm}$ & 1 & Abortusequi (1) \\
\hline 19 & $\mathrm{Na}, \mathrm{Sm}, \mathrm{T}$ & 8 & $S$. Paratyphi B var Java (3), S. Typhimurium (3), S. Saintpaul (2) \\
\hline 20 & $\mathrm{~A}, \mathrm{Ac}, \mathrm{Ce}, \mathrm{F}$ & 1 & S. Bovismorbificans (1) \\
\hline 21 & $\mathrm{~A}, \mathrm{Ac}, \mathrm{Sm}, \mathrm{T}$ & 1 & $S$. Richmond (1) \\
\hline 22 & $\mathrm{~A}, \mathrm{~F}, \mathrm{Sm}, \mathrm{T}$ & 1 & S.I. $4,5,12: \mathrm{r}, \mathrm{i}: \mathrm{i}, 5(1)$ \\
\hline 23 & $\mathrm{~A}, \mathrm{Na}, \mathrm{Sm}, \mathrm{T}$ & 1 & S. Paratyphi B var Java (1) \\
\hline 24 & $\mathrm{Cf}, \mathrm{Na}, \mathrm{Sm}, \mathrm{T}$ & 1 & $S$. Typhimurium (1) \\
\hline 25 & $\mathrm{~F}, \mathrm{G}, \mathrm{S}, \mathrm{Sm}$ & 3 & S. Abortusequi 92), $S$. Tshiongwe (1) \\
\hline 26 & $\mathrm{~F}, \mathrm{~K}, \mathrm{Na}, \mathrm{Sm}$ & 3 & S. Abortusequi (3) \\
\hline 27 & $\mathrm{~F}, \mathrm{Na}, \mathrm{Sm}, \mathrm{T}$ & 1 & S. Saintpaul (1) \\
\hline 28 & $\mathrm{~F}, \mathrm{~S}, \mathrm{Sm}, \mathrm{T}$ & 8 & $\begin{array}{l}\text { S.I. 4,5,12:ri:i,5 (5), S. Bovismorbificans (1) S. Dumfries (1), } S \text {. } \\
\text { Drogana (1) }\end{array}$ \\
\hline 29 & $\mathrm{~F}, \mathrm{~K}, \mathrm{~S}, \mathrm{Sm}$ & 1 & S. Abortusequi (1) \\
\hline 30 & $\mathrm{~A}, \mathrm{Ce}, \mathrm{F}, \mathrm{K}, \mathrm{Sm}$ & 1 & S. Abortusequi (1) \\
\hline 31 & $\mathrm{~A}, \mathrm{Cf}, \mathrm{Na}, \mathrm{Sm}, \mathrm{T}$ & 1 & S. Paratyphi B var Java (1) \\
\hline 32 & $\mathrm{~A}, \mathrm{~F}, \mathrm{~S}, \mathrm{Sm}, \mathrm{T}$ & 1 & S.I. $4,5,12: r, i: i, 5(1)$ \\
\hline 33 & $\mathrm{~A}, \mathrm{Ce}, \mathrm{S}, \mathrm{Sm}, \mathrm{T}$ & 1 & S. Drogana (1) \\
\hline 34 & $\mathrm{~A}, \mathrm{~F}, \mathrm{Na}, \mathrm{Sm}, \mathrm{T}$ & 3 & S. Paratyphi B var Java (3) \\
\hline 35 & $\mathrm{Ce}, \mathrm{C}, \mathrm{Na}, \mathrm{Sm}, \mathrm{T}$ & 1 & S. Saintpaul (1) \\
\hline 36 & $\mathrm{Ce}, \mathrm{F}, \mathrm{Na}, \mathrm{Sm}, \mathrm{T}$ & 1 & S. Paratyphi B var Java (1) \\
\hline 37 & $\mathrm{Cf}, \mathrm{F}, \mathrm{K}, \mathrm{Na}, \mathrm{Sm}$ & 2 & S. Abortusequi (2) \\
\hline 38 & $\mathrm{Cf}, \mathrm{F}, \mathrm{G}, \mathrm{K}, \mathrm{Sm}$ & 1 & S. Abortusequi (1) \\
\hline 39 & $\mathrm{~F}, \mathrm{~K}, \mathrm{Na}, \mathrm{S}, \mathrm{Sm}$ & 1 & S. Abortusequi (1) \\
\hline 40 & $\mathrm{~F}, \mathrm{G}, \mathrm{K}, \mathrm{S}, \mathrm{Sm}$ & 7 & $S$. Abortusequi (1), $S$. Dumfries (1), $S$. Newport (5) \\
\hline 41 & $\mathrm{~F}, \mathrm{~K}, \mathrm{~S}, \mathrm{Sm}, \mathrm{T}$ & 1 & S.I. $4,5,12: \mathrm{r}, \mathrm{i}: \mathrm{i}, 5$ (1) \\
\hline 42 & $\mathrm{~F}, \mathrm{~K}, \mathrm{~S}, \mathrm{Sm}, \mathrm{Tm}$ & 1 & S. Abortusequi (1) \\
\hline 43 & $\mathrm{Cf}, \mathrm{F}, \mathrm{K}, \mathrm{Na}, \mathrm{Sm}, \mathrm{Tm}$ & 1 & S. Abortusequi (1) \\
\hline 44 & $\mathrm{~F}, \mathrm{G}, \mathrm{K}, \mathrm{Na}, \mathrm{S}, \mathrm{Sm}$ & 1 & S. Abortusequi (1) \\
\hline 45 & $\mathrm{Cf}, \mathrm{F}, \mathrm{G}, \mathrm{K}, \mathrm{Na}, \mathrm{Sm}$ & 1 & S. Abortusequi (1) \\
\hline 46 & $\mathrm{~F}, \mathrm{G}, \mathrm{K}, \mathrm{S}, \mathrm{Sm}, \mathrm{T}$ & 1 & S. Newport (1) \\
\hline 47 & $\mathrm{~A}, \mathrm{Ac}, \mathrm{C}, \mathrm{F}, \mathrm{T}, \mathrm{Tm}$ & 1 & S. Paratyphi B var Java (1) \\
\hline 48 & $\mathrm{~A}, \mathrm{Ac}, \mathrm{Cf}, \mathrm{K}, \mathrm{F}, \mathrm{S}, \mathrm{Sm}$ & 1 & S. Abortusequi (1) \\
\hline 49 & $\mathrm{~A}, \mathrm{Cf}, \mathrm{F}, \mathrm{Na}, \mathrm{Sm}, \mathrm{T}$ & 1 & S. Paratyphi B var Java (1) \\
\hline 50 & $\mathrm{Ce}, \mathrm{F}, \mathrm{G}, \mathrm{K}, \mathrm{S}, \mathrm{Sm}, \mathrm{T}$ & 1 & S. Abortusequi (1) \\
\hline 51 & $\mathrm{~A}, \mathrm{Ac}, \mathrm{F}, \mathrm{S}, \mathrm{Sm}, \mathrm{T}, \mathrm{Tm}$ & 1 & S.I. 4,5,12:r,i:i,5 (1) \\
\hline
\end{tabular}


traits, even in absence of antimicrobial selection pressure, might be due to either the ability of Salmonella to build up multidrug resistance as an integral part of its genome [29] or to recent acquisition of MDR strains by equids from other animals and human beings.

Cefotaxime resistance in only $5 \%$ of isolates of Salmonella of equine origin supports recommending this drug as the safest choice for treatment of salmonellosis in equids [28]. Low levels of resistance to cefotaxime in isolates of Salmonella from equids might be attributed to either less use of this thirdgeneration cephalosporin in equids $[26,28]$ or in other animals and human beings probably due to its comparatively high cost compared to broad-spectrum and cheaper fluoroquinolones [42].

The study concludes that MDR is common among Salmonella isolates of equine origin in India. Detection of MDR in more than $75 \%$ of Salmonella strains, even in the serovars rarely causing any disease in equids, indicated that the horse is a natural host of Salmonella. Resistance to antimicrobial drugs not used in equids also suggests that either Salmonella maintains the MDR gene pool on chromosomes even in absence of selection pressure, or that Salmonella is frequently communicable between different host species or that both of the factors required in MDR development and maintenance might be important.

Acknowledgements The authors are grateful to the technical staff of the National Salmonella Centre, Izatnagar, India, for consistent help, and the Director of the Institute for financial support.

\section{References}

1. Gibbons DF (1980) Equine Salmonellosis: A review. Vet Record 19: 356-360.

2. Babu N (2003) Epidemiological studies on Salmonella infection in equines. MVSc Thesis, Indian Veterinary Research Institute, Izatnagar, India 123.

3. Singh BR, Yadav MP, Srivastava SK (2005) Development of double defined deletion mutant vaccine for Salmonella Abortusequi infection in equines. New Delhi, Competitive Grant Programme III-327, Indian Council of Agricultural Research 145.

4. Amavisit P, Browning FG, Lightfoot D, Church S, Anderson GA, Whithear KG, Markham PF (2001) Rapid PCR detection of Salmonella in horse faecal samples. Vet Microbiol 79: 6374.

5. Kilborne FL (1893) Bulletin of Bureau of Animal Industry, US Department of Agriculture 349.

6. Smith T (1893) Bulletin of Bureau of Animal Industry, US Department of Agriculture 3: 53.

7. Begg AP, Johnstan KG, Hutchins DR, Edwards DJ (1988) Some aspects of the Epidemiology of the equine Salmonellosis. Australian Vet J 65: 221-223.
8. Ozgur NY, Anzai T, Caraioglu B, Bagcigil F, Ikiz S, Ilgaz A (2001) A case of death in foal caused by Salmonella Typhimurium. Turk-veterinerlik-ve-Hayvancilik-Dergisi 25 : 721-725.

9. Weese JS, Baird JD, Poppe C, Archambault M (2001) Emergence of Salmonella Typhimurium definitive type 104 (DT-104) as an important cause of salmonellosis in horses in Ontario. Canadian Vet J 42: 788-792.

10. Gupta BR, Verma, JC, Uppal PK (1981) Occurrence of Salmonella serovars in animals in India. Indian Vet J 58: 8790.

11. Rajshekar M and Babu NGR (1992) Isolation of Salmonella Typhimurium from foals. Centaur 9: 47-48.

12. Singh BR (2005) Prevalence of Salmonella serovars in animals in India. http://www. aclisassari.com/acliopenlearning/ uploads/lectures/Methods.

13. Wray C, Sojka WJ, Bell JC (1981) Salmonella infection in horses in England and Wales: 1973-79. Vet Record 109: 398401.

14. Owen R, Fullerton J, Barnum DA (1983) Effects of transportation, surgery and antimicrobial therapy in ponies infected with Salmonella. American J Vet Res 44: 46-50.

15. Hird DW, Casebolt DV, Carter JD, Pappaionou M, Hjerpe CA (1986) Risk factors for salmonellosis in hospitalised horses. J American Vet Med Assoc 188: 173-177.

16. Pare J, Carpenter TE \& Thurmond MC (1996) Analysis of spatial and temporal clustering of horses with Salmonella karfield in an intensive care unit of a Veterinary Hospital. J Vet Med Assoc 209: 626-628.

17. Archibald L, Phillips L, Monnet D, Mcgowan JE Jr, Tenover FC, Gaynes RP (1997) Antimicrobial resistance in isolates from inpatients and outpatients in the United States: increasing importance of the intensive care unit. Clin Infect Dis 24: 211-15

18. Fraser VJ, Jones M, Dunkel J (1992) Candidaemia in a tertiary care hospital: epidemiology, risk factors, and predictors of mortality. Clin Infect Dis 5: 414-21.

19. Fridkin SK, Steward CD, Edwards JR (1999) Surveillance of antimicrobial use and antimicrobial resistance in United States hospitals: project ICARE phase 2. Clin Infect Dis 29: 245-52.

20. Rangnekar VM, Banker DD, Jhala HI (1983) Antimicrobial resistance and R-plasmids of Salmonella paratyphi A isolated in Bombay. Indian J Med Res 77: 5-9.

21. Singh BR, Singh M, Preetam, Babu N, Chandra M, Agarwal RK (2006) Prevalence of multiple drug resistant (MDR) Salmonella on betel leaves (Paan) and in water used for soaking wet betel leaves (Paan) in North Indian cities. J Food Protection 69: 288-292

22. Singh BR, Singh P, Verma A, Agrawal S, Babu N, Chandra M, Agarwal RK (2006) A study on prevalence of multi-drug resistant (MDR) Salmonella in water sprinkled on fresh vegetables in Bareilly, Moradabad, and Kanpur (Northern Indian cities). J Public Health 14: 125-131.

23. Edwards PR and Ewing WH (1972) Identification of Enterobacteriaceae. New York, Elsevier Science \& Burgees Publishing Company.

24. Clinical and Laboratory Standards Institute (CLSI) (2006) Performance standards for antimicrobial disk susceptibility tests; Approved Standard - Ninth Edition. Document M02A9, and M100-S18- Seventeenth Informational Supplement, Wayne. 
25. Singh BR, Khurana SK, Gulati BR, Mamta, Lal N (2007) Report on Studies on high-level drug resistant bacteria in equines for search of sentinel microbes to be used in predictive disease modelling and microbes with vector potential. Review Report of National Research Centre on Equines, Hissar, India. www.nrce.nic.in/project.html

26. Singh BR., Khurana SK., Chauhan M, Gulati BR (2008) Clinical problems of equine patients in India and Antimicrobial drug use. Proceedings of $8^{\text {th }}$ Indian Veterinary Congress and XV Annual Conference of IAAVR and National symposium on "Public-Private-Partnership in Veterinary Research and Education Sector, 22-24 February 2008, West Bengal University of Animal and Fishery Sciences, Kolkata 159-160.

27.Singh BR., Babu N, Jyoti J, Shankar H, Vijo T, Agrawal R, Chandra M, Kumar D, Teewari A (2007) Prevalence of multidrug-resistant Salmonella in equines in organized and unorganized sectors in India. J Equine Vet Sci 27, 266-276.

28. Sweeney CR and Boy MG (1993) Antimicrobial Drug use in horses. In Antimicrobial Therapy. In Veterinary Medicine. JF Prescot \& JD Baggot Eds. $2^{\text {nd }}$ Edn. Ames, Iowa State University Press. pp 410-426.

29. WHO (1998) Use of Quinolones in Food Animals and Potential Impact on Human Health, Report of a WHO Meeting Geneva, Switzerland 2-5 June 1998 WHO/EMC/ZDI/98.10. pp. 3-20.

30. Vishwanathan R (2006) Current Anti-biogram of Salmonella Species Isolated from Blood. J Asso Physicians India. 54, 666-667.

31. Gaind R (2003) Emerging trends of typhoid fever in India. In Proceedings of ASM conference on Salmonella: Pathogenesis, epidemiology and vaccine development. University of Sassari, Italy, 20-24 ${ }^{\text {th }}$ September 2003. pp 86

32. Chengappa MM, Staats J, Oberst RD, Gabbert NH, McVey S (1993) Prevalence of Salmonella in raw meat used in diets of racing greyhounds. J Vet Diagn Invest. 5, 372-377.

33. Steele JH (1969) Epidemiology of Salmonellosis. J American Oil Chemists' Society. 46, 219-221.

34. Chandra M, Singh BR, Shankar H, Agarwal M, Agarwal RK, Sharma G, Babu N (2006) Study on prevalence of Salmonella infection in goats. Small Ruminant Res 65: 24-30.
35. Anderson GD and Lee DR (1976) Salmonella in horses: a source of contamination of horsemeat in a packing plant under federal inspection. Appl Environ Microbiol. 31: 661663.

36. Espie E, Valk HDe, Valliant V, Quelquejeu N, Querrec FLe, Weill FX (2005) An outbreak of multidrug-resistant Salmonella enterica serotype Newport infections linked to the consumption of imported horse meat in France. Epidemiol Infect. 133, 373-376.

37. Hofer E, Zamora MRN, Lopes AE, Moura AMC de, Araujo HL de (2000) Salmonella serovars in meat of horses slaughtered in northeastern Brazil. Pesquisa Veterinária Brasileira. Pesq Vet Brasil. 20, 80-84.

38. Watson WA (1981) The Salmonella problem with particular reference to meat hygiene. J Royal Soc Promotion Hlth.101, 163-169.

39. Mammina C, Cannova L, Mass S, Goffredo E, Nastasi A (2002) Drug resistances in Salmonella isolates from animal foods, Italy 1998-2000. Epidemiol Infect 129: 155-161.

40. WHO (1997) The Medical Impact of Antimicrobial Use in Food Animals. Report of a WHO Meeting, Berlin, Germany, 13-17 October 1997. WHO/EMC/ZOO/97.4, pp. 4-21.

41. Oteo J, Aracil B, Aloes JI, Gomez-garces JL (2000) High rate of resistance to nalidixic acid in Salmonella enterica: its role as a marker of resistance to fluroquinolones. Clin Microbial Infections 6: 273-276.

42. Prescot JF and Baggot JD (1993) Fluoroquinolones. In Antimicrobial Therapy. In Veterinary Medicine. J. F. Prescot $\&$ J. D. Baggot eds. $2^{\text {nd }}$ Edn. Ames, Iowa State University Press. pp 252-261.

Corresponding Author: Bhoj Raj Singh, Principal Scientist Veterinary Microbiology, ICAR Research Complex for NEH Region, Nagaland Centre, Medziphema, Jharnapani-797 106, Nagaland, India

E-mail: brs1762@yahoo.co.in, singh_br1762@rediffmail.com

Conflict of interest: No conflict of interest is declared. 